\title{
The landscape of open innovation in Brazil: An analysis of the recent literature
}

\author{
Aline Gabriela Ferrari ${ }^{\mathrm{a}}$ (D), Janaina Aparecida Alves Scaliza ${ }^{\mathrm{a}}$ (D), Daniel Jugend ${ }^{\mathrm{a} *}$ \\ ${ }^{a}$ Departamento de Engenharia de Produção, Universidade Estadual Paulista Julio de Mesquita Filho - UNESP, Bauru, SP, Brasil \\ *daniel.jugend@unesp.br
}

\begin{abstract}
Paper aims: This article aims to identify and analyze the main studies, practices, and challenges for the adoption of open innovation (01) presented in recent Brazilian literature.

Originality: Although many studies have already been carried out in Brazil in the area of 01 , there is a lack of theoretical research which analyzes the Brazilian research in this field.

Research method: Firstly, we identified the articles on 01 in important Brazilian journals. Secondly, we carried out a qualitative analysis of these publications.

Main findings: The focus of research in the area can be divided into three main areas: (i) university-company collaboration; (ii) public support for innovation; and, (iii) integration in new product development.

Implications for theory and practice: This study presents a synthesis of results of research on 01 in the Brazilian scenario. Furthermore, we present practices and difficulties for the adoption of 01 identified by the Brazilian studies.

Keywords

Innovation. Open innovation. Collaboration for innovation. Theoretical review.
\end{abstract}

How to cite this article: Ferrari, A. G., Scaliza, J. A. A. \& Jugend, D. (2019). The landscape of open innovation in Brazil: an analysis of the recent literature. Production, v29, e20190018. D01: 10.1590/0103-6513.20190018

Received: Mar. 11, 2019; Accepted: May 19, 2019

\section{Introduction}

The last decades have challenged several firms to adopt new innovation models (Sikimic et al., 2016; Slater et al., 2014; Von Hippel, 1986). These challenges arise from companies in different parts of the world simultaneously searching for markets and new ways of organizing innovation; this creates opportunities to access new technologies, and novel supply possibilities and partnerships, not only with local companies, but also with firms in other countries. In this scenario, the Open Innovation (OI) concept as proposed by Chesbrough (2003) has been highlighted by practitioners and researchers (e.g., Laursen \& Salter, 2006; Randhawa et al., 2016; Rubera et al., 2016) because of its potential to intensify the flow of internal and external knowledge in order to improve the innovation process.

Due to recent changes in the business environment, reflected in the increasing speed of technological changes and shortened life cycle of products, it is difficult for companies to ensure their competitiveness through the unique and exclusive internal development of new technologies (D'Ambrosio et al., 2017). Therefore, many companies are developing more open ways to innovate what is also known as 01: a model in which companies more intensively use ideas and technologies developed inside and outside their borders in the innovation process (Chesbrough, 2012; Bogers et al., 2017). Furthermore, 01 also tends to provide new sources of revenue for firms through actions such as inclusion in new markets and the prospects of spin-offs and trading licenses. These 
innovation practices have the potential to increase revenue and also decrease development costs-especially those of R\&D.

Through collaboration with external and internal stakeholders, 01 has been recognized as an effective approach to improving the performance of innovation and operational processes (Jugend et al., 2018; Van de Vrande et al., 2009). In this sense, the 01 approach proposes the adoption of a set of collaborative practices, such as the intensification of partnerships with suppliers, clients, universities, research institutes, start-ups, consulting firms, and even competitors (Laursen \& Salter, 2006; Rauter et al., 2018). Furthermore, the ecosystem of innovation and the interaction of the companies within this ecosystem has also been the object of analysis by researchers involved with the themes of innovation management and 01 (e.g., Rohrbeck et al., 2009; Bogers et al., 2017).

Although the $\mathrm{Ol}$ has already been the focus of several theoretical research (e.g., Bogers et al., 2017; Randhawa et al., 2016; West \& Bogers, 2014)-and several empirical research have already been carried out in Brazil in this field-there is a lack of specific studies identifying and analyzing the most relevant articles published in that country, the most relevant journals and, finally, the main practices and challenges identified and analyzed by the Brazilian literature for the adoption of Ol. Moreover, this country is one of the largest consumer markets in the world and a member of BRICS (Brazil, Russia, India, China and South Africa). In addition, Brazil has issues that deserve to be addressed in innovation studies, such as the importance of government support in this field (Jugend et al., 2018; Negri, 2018) and the development of diverse technologies, such as biofuels (Khatiwada et al., 2016), pre-salt oil (Cavalheiro et al., 2014) and flex fuel motors (Gatti Junior, 2011), among others. Therefore, this study aims to identify and discuss these aspects about $\mathrm{Ol}$ and, thus, contribute to the advancement of this area of knowledge by identifying and analyzing specifically the Brazilian research scenario in relation to 01 .

The following section presents this research's theoretical concepts, followed by the research method, results, and a discussion of the results. Finally, we outline this study's conclusions and limitations, and some future research proposals.

\section{Open innovation}

As the $\mathrm{Ol}$ concept proposes, innovations that are usually carried out within companies, especially those in R\&D and engineering departments, currently tend to intensify external and internal means of accelerating and improving the innovation process (Van de Vrande et al., 2009; Huizingh, 2011; Chesbrough, 2012). 01 can be adopted from two streams of knowledge and technology: inbound open innovation and outbound open innovation (Mazzola et al., 2012)-also known as outside-in and inside-out processes (Mortara \& Minshall, 2011).

The acquisition and absorption of ideas, knowledge, and technologies from external sources, in addition to stimulating internal ones, is the process of inbound Ol (Bianchi et al., 2016; Slater et al., 2014). The transfer of ideas and technologies to other organizations is the outbound Ol process (Spithoven et al., 2010). Outbound can be realized, for example, through patent selling, technology licensing, and the creation of spin-offs (Chesbrough, 2006; Kutvonen, 2011). It is important to note that some studies in 01 (e.g., Gassmann \& Enkel, 2004; Sikimic et al., 2016) recommend the use of the coupled process, with integrated outbound and inbound efforts (Gassmann \& Enkel, 2004; Sikimic et al., 2016).

Collaboration with external actors and the innovation ecosystem for the integrated development of innovations and technologies is a theme widely debated by studies on 01 (e.g., Van de Vrande et al., 2009; Huizingh, 2011; Munigala et al., 2018; Pitelis \& Teece, 2018). In this sense, as observed by Holzmann et al. (2014), a fundamental activity in $\mathrm{Ol}$ is to find suitable partners for collaboration.

With regard to integration with the external environment, there is an emphasis on collaborative relationships with suppliers, customers, universities, research institutes, consultants, customers, and even competitors (Gassmann \& Enkel, 2010; Huizingh, 2011; Laursen \& Salter, 2014; Jugend et al., 2018) The existing relationships between the different partners for $\mathrm{Ol}$ are manifested in collaborative practices. Some of these practices are presented in Table 1.

Table 1. Open innovation practices.

\begin{tabular}{|c|c|}
\hline Practice & Definition \\
\hline Technology Licensing & Source of funds through the sale or offering of technological intellectual property. \\
\hline Employee Involvement & $\begin{array}{l}\text { Intensifies the participation of employees, who are not necessarily active in the areas of R\&D and engineering, in the } \\
\text { generation of innovations and development of technologies. }\end{array}$ \\
\hline Consumer Involvement & Involves customers in innovation and development of products and technologies. \\
\hline External Collaboration & Collaboration with external actors to acquire ideas, knowledge, and technologies. \\
\hline Purchase of Patents & Acquisition and use of patents. \\
\hline
\end{tabular}


The concept of 01 has been used in many different types of industries with different forms of production and markets, such as electronics, automotive, domestic utilities, and the food industry (Ades et al., 2011). The end user can be also a partner for innovation in a variety of ways, such as website interaction, co-development, customer service channels, and specific events such as best idea contests (Lorentz et al., 2016; MacCormack et al., 2013).

However, there are some barriers to the adoption of 0l. Finding appropriate external partners and motivating them to participate in the innovation process is one of these barriers (Ye \& Kankanhalli, 2013). The "not invented here syndrome"-which is an organizational culture bias which reflects a normally negative attitude on the part of company employees regarding the adoption of external sources of innovation and technology-is highlighted in the literature as an important barrier (Armellini et al., 2018; Burcharth et al., 2014; Katz \& Allen, 1982). It is also worth noting that innovation can also generate costs, called (i) identification costs related to the detection of external knowledge inputs; (ii) costs of assimilation, associated with the transfer of knowledge from outside sources to the organization that will absorb it; and (iii) costs of utilization, related to the incorporation of internal knowledge inputs to internal activities of development of new products. These costs can also be considered as barriers to the adoption of 01 .

\section{Research method}

To meet the objectives proposed for this study, a search and analysis of articles published in Brazilian journals which deal with the topic of operations management was carried out. The scope of the study meant that we considered only Brazilian journals in the areas of management and operations management and with the best evaluations in Qualis Engineering 111 during the period 2013-2016 (we considered until the evaluation 'B3'). Thus, initially the selected journals were: (i) Production; (ii) Gestão \& Produção; (iii) Revista Brasileira de Gestão de Negócios (Review of Business Management); (iv) Revista de Administração - USP (RAUSP Management Journal); (v) Revista de Administração de Empresas - FGV; (vi) Revista da Administração Pública (Brazilian Journal of Public Administration); (vii) Brazilian Administration Review. The initial choice in Engineering 111 occurred because Production journal is edited by ABEPRO - Brazilian Association of Production Engineering. We also added to these journals the following traditional publications in the fields of production engineering and innovation management: (viii) Gepros, Gestão da Produção, Operações e Sistemas; (ix) Produção Online; (x) Product: Management \& Development, (xi) Revista Gestão \& Tecnologia (Journal of Management \& Technology) and (xii) Revista Brasileira de Inovação (Brazilian Journal of Innovation).

The search was conducted using the websites of the respective journals during the month of December 2017 and this research was updated in February 2019. This search was initially performed using the keyword "innovation" in the journal database and considered the publications of the last seven years (between 2012 and 2018). We choose this period of time, since the objective of the article was to identify and analyze the recent studies in Brazil on open innovation. For this, we defined that articles published before 2012 would not be considered for this research. From the reading of the titles and abstracts of all the articles found, only those dealing with $\mathrm{Ol}$ were selected. Within this scope, articles dealing with other types of innovations (and not related to 01 ), such as innovations in information systems or knowledge management, were excluded.

Finally, we found 46 articles that addressed the topic of open innovation in these journals during the period examined. The analysis, besides classifying publications by journals, also aimed to verify the identity of the main authors, research methods used, and practices and challenges in 0l. We analyzed these practices and challenges by reading and interpreting all the selected articles (qualitative analysis). The main results obtained are presented and discussed in the next section.

\section{Presentation of results and discussion}

Table 2 shows the 46 studies identified during the period and the research methods used.

It can be observed in Table 2 that most of the Brazilian research in the 01 field has the aim of understanding the phenomenon of $\mathrm{Ol}$ by obtaining primary data, be they from companies, universities, governments, or research institutes. Approximately 70\% of the publications were operationalized through case studies (qualitative), quantitative surveys in companies, mixed methods (qualitative and quantitative), or using research action. On the other hand, only $15 \%$ of the publications were based on theoretical reviews and approximately $11 \%$ established their analysis on secondary datasets. One article used simulation method.

Among these identified publications, the authorship origin is diffuse. Only six authors have two publications. The other authors identified and presented in Table 2, and in the list of references, have only one publication. Table 3 shows publications by journals between 2012 and 2018. 
Table 2. Publications on open innovation in researched Brazilian journals (2012 to 2018).

\begin{tabular}{|c|c|}
\hline Study & Research Method \\
\hline Araujo (2012) & Qualitative \\
\hline Benavente et al. (2012) & Secondary data analysis \\
\hline Bueno \& Balestrin (2012) & Qualitative \\
\hline Caetano et al. (2012) & Research-Action \\
\hline Carvalho et al. (2018) & Quantitative \\
\hline Closs \& Ferreira (2012) & Theoretical Review \\
\hline Dewes \& Padula (2012) & Qualitative \\
\hline González et al. (2012) & Theoretical Review \\
\hline González \& Toledo (2012) & Theoretical Review \\
\hline Lopes \& Carvalho (2012) & Theoretical Review \\
\hline Pitassi (2012) & Theoretical Review \\
\hline Reame Junior \& Amaral (2012) & Qualitative \\
\hline Carrijo \& Botelho (2013) & Quantitative \\
\hline Cauchick-Miguel et al. (2013) & Qualitative \\
\hline Lara \& Guimarães (2013) & Qualitative \\
\hline Mazini et al. (2013) & Qualitative \\
\hline Silva et al. (2013a) & Qualitative \\
\hline Silva et al. (2013b) & Qualitative \\
\hline Alves \& Pimenta-Bueno (2014) & Quantitative \\
\hline Castro et al. (2014) & Quantitative \\
\hline Costa \& Porto (2014) & Mixed Methodologies (quantitative and qualitative) \\
\hline Desidério \& Zilber (2014) & Qualitative \\
\hline Freitas \& Dacorso (2014) & Secondary data analysis \\
\hline Serrano \& Gobbo Junior (2014) & Qualitative \\
\hline Vieira Filho (2014) & Theoretical Review \\
\hline Matei et al. (2015) & Mixed Methodologies (quantitative and qualitative) \\
\hline Oliveira \& Balestrin (2015) & Qualitative \\
\hline Ribeiro \& Porto (2015) & Quantitative \\
\hline Rocha (2015) & Secondary data analysis \\
\hline Schaeffer et al. (2015) & Quantitative \\
\hline Fernandes et al. (2016) & Mixed Methodologies (quantitative and qualitative) \\
\hline Moreira et al. (2016) & Quantitative \\
\hline Prim et al. (2016) & Quantitative \\
\hline Silva et al. (2016) & Qualitative \\
\hline Stal \& Fujino (2016) & Theoretical Review \\
\hline Vieira \& Bonifácio-da-Silva (2016) & Quantitative \\
\hline Cunico et al. (2017) & Quantitative \\
\hline Gielfi et al. (2017) & Secondary data analysis \\
\hline Lopes et al. (2017) & Mixed Methodologies (quantitative and qualitative) \\
\hline Rolt et al. (2017) & Mixed Methodologies (quantitative and qualitative) \\
\hline Betim et al. (2018) & Qualitative \\
\hline Enrique et al. (2018) & Quantitative \\
\hline Mendonça et al. (2018) & Qualitative \\
\hline Merino et al. (2018) & Simulation \\
\hline Oliveira et al. (2018) & Qualitative \\
\hline Paula \& Silva (2018) & Secondary data analysis \\
\hline
\end{tabular}

Table 3 indicates that publications on 01 in these journals have remained stable over the review period. Only in 2012 was there a slightly larger number of publications when compared with the rest of the examined period (2013-2018). Notably, of the journals analyzed, the ones that have published most research on the topic are Gestão \& Produção and Revista Brasileira de Inovação, followed by the journals Production; and Product: Management \& Development.

In the analysis of the articles surveyed, we observed that the focus of the research on 01 in Brazil is divided, mainly, into three areas: (i) collaboration between universities and companies; (ii) public support for innovation; and, (iii) external involvement in new product development. The next paragraphs address the findings of each of these areas. 
Table 3. Publications in journals on open innovation (2012 to 2018).

\begin{tabular}{|c|c|c|c|c|c|c|c|c|}
\hline \multirow{2}{*}{ Journal } & \multicolumn{8}{|c|}{ Year } \\
\hline & 2012 & 2013 & 2014 & 2015 & 2016 & 2017 & 2018 & TOTAL \\
\hline Brazilian Administration Review & 0 & 0 & 0 & 0 & 2 & 0 & 1 & 3 \\
\hline Gestão \& Produção & 2 & 0 & 0 & 2 & 0 & 2 & 2 & 8 \\
\hline Gepros. Gestão da Produção, Operações e Sistemas & 0 & 1 & 1 & 0 & 0 & 0 & 0 & 2 \\
\hline Production & 2 & 0 & 1 & 0 & 0 & 0 & 2 & 5 \\
\hline Produção Online & 0 & 1 & 0 & 0 & 1 & 0 & 0 & 2 \\
\hline Product: Management \& Development & 2 & 2 & 0 & 0 & 0 & 0 & 1 & 5 \\
\hline Revista Brasileira de lnovação & 2 & 1 & 2 & 2 & 0 & 1 & 0 & 8 \\
\hline Revista da Administração RA - USP & 0 & 0 & 0 & 0 & 2 & 1 & 0 & 3 \\
\hline Revista de Administração de Empresas RAE & 1 & 0 & 1 & 0 & 0 & 0 & 0 & 2 \\
\hline Revista da Administração Pública & 1 & 0 & 1 & 0 & 0 & 0 & 0 & 2 \\
\hline Revista Brasileira de Gestão de Negócios & 0 & 0 & 0 & 1 & 1 & 0 & 0 & 2 \\
\hline Revista Gestão \& Tecnologia & 1 & 1 & 1 & 0 & 0 & 0 & 1 & 4 \\
\hline TOTAL & 11 & 6 & 7 & 5 & 6 & 4 & 7 & 46 \\
\hline
\end{tabular}

\section{- Collaboration between universities and companies}

The collaboration between universities and companies as a means to boost 01 is the object of research of most of the studies identified (Alves \& Pimenta-Bueno, 2014; Castro et al., 2014; Carrijo \& Botelho, 2013; Closs \& Ferreira, 2012; Fernandes et al., 2016; Gielfi et al., 2017; Matei et al., 2015; Oliveira \& Balestrin, 2015; Schaeffer et al., 2015; Silva et al., 2013b; Stal \& Fujino, 2016). Closs \& Ferreira (2012) point out that university-company collaboration tends to be positive for companies because, in addition to reducing innovation costs, it also allows greater access to qualified people and university structures, especially laboratories. The findings of Castro et al. (2014) suggest that the company-university relationship in Brazil tends to improve the innovative performance of firms. Analyzing the innovation ecosystem of the city of Belo Horizonte, Mendonça et al. (2018) noted that the presence of many industries and universities and the support of research institutions (e.g., FAPEMIG) facilitate the exchange of knowledge, which occurs mainly through contact between employees and professors and researchers.

Cauchick-Miguel et al. (2013) observed in their study of a large cosmetics company that open innovation initiatives began in the 90s and that the company's partnerships included more than twenty universities and research institutes in Brazil and abroad. Among the results were observed several kinds of collaborations, such as cooperation, co-creation, co-design, financing and consulting. Investigating a large aeronautical company in Brazil, Araujo (2012) identified advantages and disadvantages in academic partnership projects. Among the advantages were integration of technical and specialized knowledge with university projects, increased networking with researchers, and access to specialized laboratories. On the other hand, differences in deadline expectations between industry and academia and difficulties in negotiations involving intellectual property were some of the disadvantages observed.

Although many studies on $\mathrm{Ol}$ address efforts to analyze the university-company relationship, some of these indicate that there are difficulties inherent in carrying out this kind of collaboration in Brazil (Closs \& Ferreira, 2012; Alves \& Pimenta-Bueno, 2014; Fernandes et al., 2016). For example, Fernandes et al. (2016) observed that universities-notably engineering schools-contribute more to workforce formation than to economic collaborations with industries. Among other difficulties identified, notable problems are: the resistance of many universities to the realization of partnerships with companies (Stal \& Fujino, 2016); the existence of a short-term corporate vision which does not take into account the terms of scientific projects; the lack of institutional mechanisms for brokering and access to information regarding scientific production; bureaucratic and legal aspects; teams that are unprepared to manage cooperation projects; and difficulties in transferring incipient research results to the market (Araujo, 2012; Closs \& Ferreira, 2012; Alves \& Pimenta-Bueno, 2014). Difficulties related to reduced structure of university innovation agencies and communication between these agencies and the market were also identified (Desidério \& Zilber, 2014).

Finally, in this area of collaboration university -company, Petrobras stands out as the company which leads university-company research (Alves \& Pimenta-Bueno, 2014; Gielfi et al., 2017; Matei et al., 2015). In addition to its importance to Brazil, as reported by Gielfi et al. (2017), this emphasis occurs mainly because Petrobras has an extensive network of scientific collaborations dispersed throughout the country. 


\section{- Public support for innovation}

Support from and collaboration with the public sector as a way to boost innovation in firms has also been the focus of Brazilian research into 01 (Dewes \& Padula, 2012; Carrijo \& Botelho 2013; Vieira Filho, 2014; Ribeiro \& Porto, 2015; Rocha, 2015). In this sense, Jugend et al. (2018) verified the importance of governmental support for the adoption of 01 practices in Brazil. Part of this area of research is devoted to analyzing government support for innovation in specific sectors of the Brazilian economy such as aerospace (Dewes \& Padula, 2012), agro-industry (Vieira Filho, 2014), and energy and biotechnology (Ribeiro \& Porto, 2015). Other studies have focused on examining results from government programs, such as the Program to Support Research in Firms (Programa de Apoio à Pesquisa em Empresas - PAPPE) (Carrijo \& Botelho, 2013) and even the general results of government support for investments in R\&D in the country's industry (Rocha, 2015).

In this context of public sector support for innovation, based on the Triple Helix Model and the concept of industrial cluster, Oliveira et al. (2018) presented and analyzed the case of lnatel's Business Engineering Incubator; they observed that incubator participation is relevant for the development of local clusters. Even with public support, through financial resources from the Sectoral Funds for Science \& Technology for the biotechnology and energy sectors, the number of patents generated by Brazilian companies remains below expectations (Ribeiro \& Porto, 2015).

\section{- External involvement in new product development}

Specific studies involving the integration of diverse stakeholders in new product projects-such as customers, suppliers, and universities-have also drawn the attention of researchers involved with the 01 field (Bueno \& Balestrin, 2012; Enrique et al., 2018; González \& Toledo, 2012; Reame Junior \& Amaral, 2012; Mazini et al., 2013; Merino et al., 2018). Using the simulation method to analyze relations between new product development and 01, Merino et al. (2018) verified that the generation and absorption of external knowledge and entry of new competitors can accelerate the innovation process, which tends to promote differentiation of value for the consumer and greater visibility of the product in the market.

Mazini et al. (2013) analyzed a project of a car concept through the Web 2.0 and the issues about co-development involving users in various stages of the new product development. Reame Junior \& Amaral (2012) observed that factors such as trust, commitment, documented learning, team continuity, and good relationship are key elements for the good performance of these collaborative relationships in new product development projects. Enrique et al. (2018) noted that information and communication technology tools are important to support collaborative practices between different partners in new product development processes, because these boost communication and cooperation in these kinds of projects.

In addition to these three dimensions, other issues were highlighted by the identified and analyzed articles. It should also be noted that "performance" is defined by Carrijo \& Botelho (2013), as the generation of patents, new jobs, publication of articles, and product insertion into new markets. Merino et al. (2018) emphasize that the opening of innovative processes can lead to the increase of potential and effective consumers Silva et al. (2016) investigated the relationships of small business partnerships with external agents, and their results showed that the relationship between external agents and small firms favors innovative performance. In regional clusters, Prim et al. (2016) found that firms that access additional resources with greater intensity tend to improve product and process innovation and export performance.

It is worth mentioned that, among these studies about 01, only Castro et al. (2014) raise the issue of technology licensing as an 01 practice. Few studies address the issue of patents (Carrijo \& Botelho, 2013; Serrano \& Gobbo Junior, 2014; Ribeiro \& Porto, 2015). Relating 01 to sustainability and environment was only found in the research study by Cunico et al. (2017). Considering that concerns about the development of technologies oriented toward environmental sustainability, especially in the circular economy and sharing economy, has received the attention of many researchers (Jabbour et al., 2017; Plewnia \& Guenther, 2018), this may be a trend for research into 01 .

Lara \& Guimarães (2013) identified the possible barriers to innovation in companies in the metal-mechanical sector. These barriers include aversion to financial risk, difficulties in acquiring materials, aversion to increased investment, and lack of government incentives. In the scope of the Brazilian public administration, the study by Freitas \& Dacorso (2014) indicated that the government has been moving toward 01 and that this has been done through the use of information technology

Finally, although the findings of Carvalho et al. (2018) highlighted the formation of personal and interorganizational trust as keys to the establishment of partnerships for innovation, we did not observe Brazilian studies focused on organizational culture in 01 and the "not invented here syndrome"; which is recognized worldwide as one 
of the main barriers to the adoption of 01 (Armellini et al., 2018; Burcharth et al., 2014). Future studies could analyze this aspect, taking into consideration the particularities of the Brazilian organizational culture.

\section{Final remarks}

This article aimed to evaluate studies published in Brazilian journals in the production engineering and management fields which address 0l, detailing the types of research used, and the most analyzed and disseminated practices. We understand that the results of this research contribute to the areas of innovation management, especially considering the context of an emerging country.

At the same time, it was noted that the Brazilian publications emphasize the relationship of partnerships for innovation between companies and universities; it was also observed that these relations tend to present relevant challenges, such as: the resistance of some universities toward promoting this type of collaboration and the lack of preparation of teams to manage the cooperation projects. Building on these results, future research could investigate ways to improve the collaboration between Brazilian universities with companies and even propose possible governance mechanisms for this collaboration. Future research results focused on this issue could also contribute to the improvement of the quality of the innovation ecosystem in Brazil.

The results of this study also show that the authorship of the studies is diverse, without any particular authors, research groups or universities being prominent in the analyzed journals. Although there is no Brazilian journal that presents a hegemonic number of publications on 01, it was noticed that 'Gestão \& Produção', and 'Revista Brasileira de Inovação' stand out in relation to the other journals analyzed herein.

The results of this work show that there are few studies on $\mathrm{Ol}$ related to some of the main trends in operations management, such as Industry 4.0, big data, artificial intelligence, and circular economy. Future studies could show relationships between $\mathrm{Ol}$ and these themes, taking into account the realities of Brazil or other emerging countries. Moreover, additional research could relate $\mathrm{Ol}$ and innovative performance, but in a manner consistent with the Brazilian innovation reality. Furthermore, we did not find studies on the organizational culture of Brazilian companies and their relationship to the adoption of $\mathrm{Ol}$ practices. These themes may be avenues of future research.

Among the theoretical implications, this study presents, in an integrated manner, the synthesis of results of recent research on $\mathrm{Ol}$ in the Brazilian landscape. Among the managerial implications, we present practices as well as difficulties for the adoption of $\mathrm{Ol}$ identified by the studies in Brazil. We understand that the presentation of these practices and challenges have the potential to guide managers interested in improving the innovation process, especially considering the 01 perspective.

Finally, it is recognized that this research has limitations. The main limitations are that only qualitative analysis was performed and only certain Brazilian journals were considered and still limited to a period of time (seven years to search for articles). Future research could broaden the results of this work by integrating other journals and the main Brazilian conferences that attract studies on 0l. The expansion of the years of search of articles could also be considered in future researches Bibliometric studies in databases such as Scopus, Web of Science, and SciELO could also complement and deepen the results presented and discussed in this article.

\section{Acknowledgment}

The authors would like to thank FAPESP for supporting this project (nº17/14901-0).

\section{References}

Ades, C., Sbragia, R., Porto, G., Plonsky, G. A., Figlioli, A., \& Celadon, K. (2011). Implementação da inovação aberta: os casos da Natura, IBM e Siemens. In: Associação Latino-lberoamericana da Gestão da Tecnologia, XIV Congresso Latino-lberoamericano de Gestión Tecnológica: Innovación para el crecimiento sostenible en el marco del bicentenario, (pp. 1-16). Lima, Peru: ALTEC.

Alves, A. S., \& Pimenta-Bueno, J. A. (2014). Uma análise exploratória do financiamento público à interação universidade-empresa no Brasil. Produção, 24(4), 898-910.

Araujo, C. S. (2012). Lessons learned on the planning and execution of technology innovation projects with academic partnership: aerospace industry case study. Product: Management \& Development, 10(1), 41-51. http://dx.doi.org/10.4322/pmd.2012.013.

Armellini, F., Beaudry, C., \& Mahon, M. (2018). The influence of the NIH and NSH syndromes on the adoption of open innovation in the Canadian aerospace sector. In: Grajö, U., Karlosson, C., \& Bernhard, I. (Eds.), Geography, Open Innovation and Entrepreneurship, Edward Elgar Publishing: Cheltenham, UK. http://dx.doi.org/10.4337/9781786439901.00009.

Benavente, J. M., Crespi, G., \& Maffioli, A. (2012). Apoio público à inovação empresarial: uma avaliação do Programa FONTEC. Revista Brasileira de Inovação, 11, 113-152. http://dx.doi.org/10.20396/rbi.v11i0.8649039. 
Betim, L. M., Resende, L. M., Andrade Junior, P. P., Pontes, J., \& Petter, R. R. H. (2018). Relações verticais e horizontais no processo de inovação e aprendizagem interativa: estudo em um aglomerado produtivo. Gestão \& Produção, 25(2), 205-218. http://dx.doi. org/10.1590/0104-530x1028-16.

Bianchi, M., Croce, A., Dell'Era, C., Di Benedetto, C. A., \& Frattini, F. (2016). Organizing for Inbound Open Innovation: How external consultants and a dedicated R\&D Unit influence product innovation performance. Journal of Product Innovation Management, 33(4), 492-510. http://dx.doi.org/10.1111/jpim.12302.

Bogers, M., Zobel, A. K., Afuah, A., Almirall, E., Brunswicker, S., Dahlander, L., \& Hagedoorn, J. (2017). The open innovation research landscape: Established perspectives and emerging themes across different levels of analysis. Industry and lnnovation, 24(1), 8-40. http://dx.doi.org/10.1080/13662716.2016.1240068.

Bueno, B., \& Balestrin, A. (2012). Inovação colaborativa: uma abordagem aberta no desenvolvimento de novos produtos. RAE-Revista de Administração de Empresas, 52(5), 517-530.

Burcharth, A. L. A., Knudsen, M. P., \& Søndergaard, H. A. (2014). Neither invented nor shared here: The impact and management of attitudes for the adoption of open innovation practices. Technovation, 34(3), 149-161. http://dx.doi.org/10.1016/j.technovation.2013.11.007.

Caetano, M., Schnetzler, J. P., \& Amaral, D. C. (2012). Incorporação de parcerias no planejamento estratégico da inovação em uma estratégia technology push de integração. Revista Gestão \& Tecnologia, 12(2), 89-112.

Carrijo, M. C., \& Botelho, M. R. A. (2013). Cooperação e inovação: uma análise dos resultados do Programa de Apoio à Pesquisa em Empresas (Pappe). Revista Brasileira de Inovação, 12(2), 417-448. http://dx.doi.org/10.20396/rbi.v12i2.8649067.

Carvalho, N., Zanquetto Filho, H., \& Oliveira, M. P. V. (2018). Confiança interorganizacional e cooperação em habitats de inovação. Revista Gestão \& Tecnologia, 18(1), 88-114. http://dx.doi.org/10.20397/2177-6652/2018.v18i1.1183.

Castro, P. G., Silva Teixeira, A. L., \& Lima, J. E. (2014). A relação entre os canais de transferência de conhecimento das Universidades/ IPPS e o desempenho inovativo das firmas no Brasil. Revista Brasileira de Inovação, 13(2), 345-370. http://dx.doi.org/10.20396/ rbi.v13i2.8649082.

Cauchick-Miguel, P. A., Carvalho, M. M. D., \& Lopes, A. P. V. B. (2013). A pilot case study of open innovation in a Brazilian company. Product: Management \& Development, 11(2), 136-141. http://dx.doi.org/10.4322/pmd.2013.022.

Cavalheiro, C. G. M., Joia, L. A., \& Gonçalves, A. C. (2014). Strategic patenting in the upstream oil and gas industry: Assessing the impact of the pre-salt discovery on patent applications in Brazil. World Patent Information, 39, 58-68. http://dx.doi.org/10.1016/j. wpi.2014.04.003.

Chesbrough, H. (2012). Inovação aberta: como criar e lucrar com a tecnologia. Porto Alegre: Bookman.

Chesbrough, H. W. (2003). The era of open innovation. MIT Sloan Management Review, 44(3), 35-41.

Closs, L., \& Ferreira, G. C. (2012). A transferência de tecnologia universidade-empresa no contexto brasileiro: uma revisão de estudos científicos publicados entre os anos 2005 e 2009. Gestão \& Produção, 19(2), 419-432. http://dx.doi.org/10.1590/S0104-530X2012000200014.

Costa, P. R., \& Porto, G. S. (2014). Governança tecnológica e cooperabilidade nas multinacionais brasileiras. RAE-Revista de Administração de Empresas, 54(2), 201-221. http://dx.doi.org/10.1590/S0034-759020140207.

Cunico, E., Cirani, C. B. S., Lopes, E. L. L., \& Jabbour, C. J. C. (2017). Eco-innovation and technological cooperation in cassava processing companies: structural equation modeling. Revista ADM, 52(1), 36-46. http://dx.doi.org/10.1016/j.rausp.2016.09.006.

D’Ambrosio, A., Gabriele, R., Schiavone, F., \& Villasalero, M. (2017). The role of openness in explaining innovation performance in a regional context. The Journal of Technology Transfer, 42(2), 389-408. http://dx.doi.org/10.1007/s10961-016-9501-8.

Desidério, P. H. M., \& Zilber, M. A. (2014). Barreiras no processo de transferência tecnológica entre agências de inovação e empresas: observações em instituições públicas e privadas. Revista Gestão \& Tecnologia, 14(2), 101-126.

Dewes, M. F., \& Padula, A. D. (2012). Inovação em um programa estratégico de desenvolvimento: o Programa Espacial Brasileiro. Revista Brasileira de Inovação, 11(1), 167-192. http://dx.doi.org/10.20396/rbi.v11i1.8649030.

Enrique, D. V., Ayala, N. F., Lima, M. J. D. R. F., Marodin, G. A., Gzara, L., \& Frank, A. G. (2018). The use of ICT tools to support collaborative product development activities: evidences from Brazilian industry. Production, 28(0), 28. http://dx.doi.org/10.1590/01036513.20170099

Fernandes, J., Leal, É. D. A. S., Gonçalves, G. P., \& Teixeira, R. B. (2016). Interação universidade-empresa no estado do espírito santo: o papel das engenharias. Revista Produção Online, 16(4), 1412. http://dx.doi.org/10.14488/1676-1901.v16i4.2355.

Freitas, R. K. V., \& Dacorso, A. L. R. (2014). Inovação aberta na gestão pública: análise do plano de ação brasileiro para a Open Government Partnership. Revista de Administração Pública, 48(4), 869-888. http://dx.doi.org/10.1590/0034-76121545.

Gassmann, 0., \& Enkel, E. (2004). Towards a theory of open innovation: three core process archetypes. In: P. Maskell, K. Laursen, \& S. Ozcan, Proceedings of the R\&D Management Conference, Lisbon, Portugal.

Gatti Junior, W. (2011). 0 envolvimento de fornecedores no desenvolvimento da tecnologia flex fuel nas montadoras brasileiras. Revista Gestão \& Tecnologia, 11(1), 87-105.

Gielfi, G. G., Furtado, A. T., Campos, A. S., \& Tijssen, R. (2017). A interação universidade-empresa na indústria de petróleo brasileira: o caso da Petrobras. Revista Brasileira de Inovação, 16(2), 325-350.

González, M. O. A., Galvão, M. S., Falani, S. Y. A., Gonçalves, J. S., \& Silva, L. T. S. (2012). Open innovation practices in the development of wind energy supply chain: an exploratory analysis of the literature. Product: Management \& Development, 10(2), 104-111. http:// dx.doi.org/10.4322/pmd.2013.004.

González, M. O. A., \& Toledo, J. C. (2012). A integração do cliente no processo de desenvolvimento de produto: revisão bibliográfica sistemática e temas para pesquisa. Production, 22(1), 14-26. http://dx.doi.org/10.1590/S0103-65132011005000065.

Holzmann, T., Sailer, K., Galbraith, B., \& Katzy, B. R. (2014). Matchmaking for open innovation-theoretical perspectives based on interaction, rather than transaction. Journal Technology Analysis \& Strategic Management, 26(4), 595-599. http://dx.doi.org/10. 1080/09537325.2014.913344.

Huizingh, E. K. (2011). Open innovation: State of the art and future perspectives. Technovation, 31(1), 2-9. http://dx.doi.org/10.1016/j. technovation.2010.10.002. 
Jabbour, C. J. C., Sousa Jabbour, A. B. L., Sarkis, J., \& Godinho Filho, M. (2017). Unlocking the circular economy through new business models based on large-scale data: an integrative framework and research agenda. Technological Forecasting and Social Change (in press). http://dx.doi.org/10.1016/j.techfore.2017.09.010.

Jugend, D., Jabbour, C. J. C., Scaliza, J. A. A., Rocha, R. S., Junior, J. A. G., Latan, H., \& Salgado, M. H. (2018). Relationships among open innovation, innovative performance, government support and firm size: Comparing Brazilian firms embracing different levels of radicalism in innovation. Technovation, 74, 54-65. http://dx.doi.org/10.1016/j.technovation.2018.02.004.

Katz, R., \& Allen, T. J. (1982). Investigating the Not Invented Here (NIH) syndrome: A look at the performance, tenure, and communication patterns of 50 R\&D Project Groups. $R \&$ D Management, 12(1), 7-20. http://dx.doi.org/10.1111/j.1467-9310.1982.tb00478.x.

Khatiwada, D., Leduc, S., Silveira, S., \& McCallum, 1. (2016). Optimizing ethanol and bioelectricity production in sugarcane biorefineries in Brazil. Renewable Energy, 85, 371-386. http://dx.doi.org/10.1016/j.renene.2015.06.009.

Kutvonen, A. (2011). Strategic application of outbound open innovation. European Journal of Innovation Management, 14(4), 460-474. http://dx.doi.org/10.1108/14601061111174916.

Lara, F. F., \& Guimarães, M. R. N. (2013). Inovação organizacional: estudos de caso comparativos entre duas empresas de pequeno porte e duas empresas subsidiárias do setor metal-mecânico da região de Sorocaba. Gepros: Gestão da Produção. Operações e Sistemas, 8(1), 96-107.

Laursen, K., \& Salter, A. (2006). Open for innovation: the role of openness in explaining innovation performance among UK manufacturing firms. Strategic Management Journal, 27(2), 131-150. http://dx.doi.org/10.1002/smj.507.

Laursen, K., \& Salter, A. J. (2014). The paradox of openness: Appropriability, external search and collaboration. Research Policy, 43(5), 867-878. http://dx.doi.org/10.1016/j.respol.2013.10.004.

Lopes, A. P. V. B. V., \& Carvalho, M. M. (2012). Evolução da literatura de inovação em relações de cooperação: um estudo bibliométrico num período de vinte anos. Gestão \& Produção, 19(1), 203-217. http://dx.doi.org/10.1590/S0104-530X2012000100014.

Lopes, A. P. V. B. V., Ferrarese, A., \& Carvalho, M. M. (2017). Inovação aberta no processo de pesquisa e desenvolvimento: uma análise da cooperação entre empresas automotivas e universidades. Gestão \& Produção, 24(4), 653-666. http://dx.doi.org/10.1590/0104530x2138-16.

Lorentz, R., Lhéritier, A. M. P., \& Aoussat, A. (2016). Innovation intermediation at the new product development level: a case study in the bio-industrial sectors. International Journal of Product Development, 21(2-3), 97-116. http://dx.doi.org/10.1504/IJPD.2016.078858.

MacCormack, A., Murray, F., \& Wagner, E. (2013). Spurring innovation through competitions. MIT Sloan Management Review, $55(1), 25$.

Matei, A. P., ten Caten, C. S., Zouain, R. N. A., \& Sant'Anna, Â. M. O. (2015). Análise do impacto dos projetos de interação entre a UFRGS e a PETROBRAS. Gestão \& Produção, 22(4), 789-804. http://dx.doi.org/10.1590/0104-530X25298-14.

Mazini, S. R., Gobbo Junior, J. A., Jugend, D., \& Silva, S. L. D. (2013). Open innovation and user s involvement in new product development: a case study in the automotive sector. Product: Management \& Development, 11(1), 49-55. http://dx.doi.org/10.4322/pmd.2013.013.

Mazzola, E., Bruccoleri, M., \& Perrone, G. (2012). The effect of inbound, outbound and coupled innovation on performance. International Journal of Innovation Management, 16(06), 1-26. http://dx.doi.org/10.1142/S1363919612400087.

Mendonça, B. R. C., Liboreiro, K., Alves, L. L., Nakashima, C. Y., \& Romeiro, E. (2018). Innovative contribution of subsidiaries to the parent company: a hypothesis about the relationship between an aerospace company and its subsidiary in Belo Horizonte. Product: Management \& Development, 16(1), 53-60. http://dx.doi.org/10.4322/pmd.2018.006.

Merino, E. A. D., Forcellini, F. A., Neto, R. A., \& Wagner, A. (2018). Modelo para avaliar o comportamento dinâmico da evolução da comercialização de produtos em um contexto de inovação aberta. Gestão \& Produção, 25(3), 645-657. http://dx.doi.org/10.1590/0104530x1594-14.

Moreira, F. G. P. V., Torkomian, A. L., Soares, T. (2016). Exploration e o desempenho inovador da firma: como funciona essa relação? Revista Brasileira de Gestão de Negócios, 18(61), 392-415.

Mortara, L., \& Minshall, T. (2011). How do large multinational companies implement open innovation? Technovation, 31(10-11), 586597. http://dx.doi.org/10.1016/j.technovation.2011.05.002.

Munigala, V., Oinonen, P., \& Ekman, K. (2018). Envisioning future innovative experimental ecosystems through the foresight approach. Case: Design Factory. European Journal of Futures Research, 6(1), 1-16. http://dx.doi.org/10.1007/s40309-017-0128-2.

Negri, F. (2018). Novos caminhos para a inovação no Brasil (Organizadores: Wilson Center). Washington: Interfarma.

Oliveira, A. H. D., Marins, F. A. S., \& Delamaro, M. C. (2018). Business engineering incubators: a cooperation case for cluster's development. Production, 28(0), 1-16. http://dx.doi.org/10.1590/0103-6513.20180001.

Oliveira, S. R., \& Balestrin, A. (2015). Cooperação universidade-empresa: um estudo do projeto UNISINOS - HT Micron para o desenvolvimento de capacidade absortiva na área de semicondutores. Gestão \& Produção, 25(3), 595-609. http://dx.doi.org/10.1590/0104-530x1018-13.

Paula, F. D. O., \& Silva, J. F. D. (2018). Balancing Internal and External R\&D Strategies to Improve Innovation and Financial Performance. BAR - Brazilian Administration Review, 15(2). http://dx.doi.org/10.1590/1807-7692bar2018170129.

Pitassi, C. (2012). A virtualidade nas estratégias de inovação aberta: proposta de articulação conceitual. Revista de Administração Pública, 46(2), 619-641. http://dx.doi.org/10.1590/S0034-76122012000200013.

Pitelis, C. N., \& Teece, D. J. (2018). The New MNE: 'Orchestration'Theory as Envelope of 'Internalisation' Theory. Management International Review, 58(4), 1-17. http://dx.doi.org/10.1007/s11575-018-0346-2.

Plewnia, F., \& Guenther, E. (2018). Mapping the sharing economy for sustainability research. Management Decision, 56(3), 570-583. http://dx.doi.org/10.1108/MD-11-2016-0766.

Prim, A. L., Amal, M., \& Carvalho, L. (2016). Regional cluster, innovation and export performance: an empirical study. BAR - Brazilian Administration Review, 13(2). http://dx.doi.org/10.1590/1807-7692bar2016160028.

Randhawa, K., Wilden, R., \& Hohberger, J. (2016). A bibliometric review of open innovation: Setting a research agenda. Journal of Product Innovation Management, 33(6), 750-772. http://dx.doi.org/10.1111/jpim.12312.

Rauter, R., Globocnik, D., Perl-Vorbach, E., \& Baumgartner, R. J. (2018). Open innovation and its effects on economic and sustainability innovation performance. Journal of Innovation \& Knowledge, 1-13. 
Reame Junior, E., \& Amaral, D. C. (2012). Fatores críticos de sucesso em projetos colaborativos na indústria de máquinas agrícolas. Production, 22(4), 696-708. http://dx.doi.org/10.1590/S0103-65132012005000051.

Ribeiro, W. L., \& Porto, G. S. (2015). Analyses of innovation networks financed by biotechnology and energy sector funds. Revista brasileira de gestão de negócios, 17(58), 1426-1443. http://dx.doi.org/10.7819/rbgn.v17i58.1764.

Rocha, F. (2015). Qual o efeito do apoio governamental à inovação sobre o gasto empresarial em P\&D? Evidências do Brasil. Revista Brasileira de Inovação, 14, 37-60. http://dx.doi.org/10.20396/rbi.v14i0.8649099.

Rohrbeck, R., Hölzle, K., \& Gemünden, H. G. (2009). Opening up for competitive advantage-How Deutsche Telekom creates an open innovation ecosystem. $R \& D$ Management, 39(4), 420-430. http://dx.doi.org/10.1111/j.1467-9310.2009.00568.x.

Rolt, C. R., Dias, J. S., \& Peña, F. T. G. (2017). Network analysis as a management tool for inter-organizational projects. Gestão \& Produção, 24(2), 266-278.

Rubera, G., Chandrasekaran, D., \& Ordanini, A. (2016). Open innovation, product portfolio innovativeness and firm performance: the dual role of new product development capabilities. Journal of the Academy of Marketing Science, 44(2), 166-184. http://dx.doi. org/10.1007/s11747-014-0423-4.

Schaeffer, P. R., Ruffoni, J., \& Puffal, D. (2015). Razões, benefícios e dificuldades da interação universidade-empresa. Revista Brasileira de Inovação, 14(1), 105-134. http://dx.doi.org/10.20396/rbi.v14i1.8649091.

Serrano, B. P., \& Gobbo Junior, J. A. (2014). Redes de inovação: mapeamento de inventores de patentes em uma empresa do setor de cosméticos. Gepros: Gestão da Produção. Operações e Sistemas, 9(1), 101.

Sikimic, U., Chiesa, V., Frattini, F., \& Scalera, V. G. (2016). Investigating the influence of technology inflows on technology outflows in open innovation processes: a longitudinal analysis. Journal of Product Innovation Management, 33(6), 652-669. http://dx.doi. org/10.1111/jpim.12319.

Silva, B. E., Ramos Neves, J. T., Vasconcelos, M. C. R. L., \& Araújo, C. A. Á. (2013a). Contribuições da inovação aberta para uma empresa de comunicação. Revista Gestão \& Tecnologia, 13(2), 222-246.

Silva, G., Dacorso, A. L. R., Costa, V. B., \& Serio, L. C. D. (2016). Relationships and partnerships in small companies: strengthening the business through external agents. BAR - Brazilian Administration Review, 13(1), 1-18. http://dx.doi.org/10.1590/1807-7692barnaahead0116.

Silva, L. C. S., Kovaleski, J. L., \& Gaia, S. (2013b). Gestão do conhecimento organizacional visando à transferência de tecnologia: os desafios enfrentados pelo NIT da universidade estadual de Santa Cruz. Revista Produção Online, 13(2), 677-702. http://dx.doi. org/10.14488/1676-1901.v13i2.1314

Slater, S. F., Mohr, J. J., \& Sengupta, S. (2014). Radical product innovation capability: Literature review, synthesis, and illustrative research propositions. Journal of Product Innovation Management, 31(3), 552-566. http://dx.doi.org/10.1111/jpim.12113.

Stal, E., \& Fujino, A. (2016). The evolution of universities' relations with the business sector in Brazil: What national publications between 1980 and 2012 reveal. Revista ADM, 51(1), 72-86.

Spithoven, A., Clarysse, B., \& Knockaert, M. (2010). Building absorptive capacity to organise inbound open innovation in traditional industries. Technovation, 30(2), 130-141. http://dx.doi.org/10.1016/j.technovation.2009.08.004.

Van de Vrande, V., De Jong, J. P., Vanhaverbeke, W., \& De Rochemont, M. (2009). Open innovation in SMEs: Trends, motives and management challenges. Technovation, 29(6-7), 423-437. http://dx.doi.org/10.1016/j.technovation.2008.10.001.

Vieira Filho, J. E. R. (2014). Políticas públicas de inovação no setor agropecuário: uma avaliação dos fundos setoriais. Revista Brasileira de Inovação, 13(1), 109-132. http://dx.doi.org/10.20396/rbi.v13i1.8649073.

Vieira, V. A., \& Bonifácio-da-Silva, W. (2016). An analysis of the relationship between embedded ties and supplier innovation in the cooperative sector. Revista ADM, 51(4), 386-396. http://dx.doi.org/10.1016/j.rausp.2016.07.003.

Von Hippel, E. (1986). Lead users: a source of novel product concepts. Management Science, 32(7), 791-805. http://dx.doi.org/10.1287/ mnsc.32.7.791.

West, J., \& Bogers, M. (2014). Leveraging external sources of innovation: a review of research on open innovation. Journal of Product Innovation Management, 31(4), 814-831. http://dx.doi.org/10.1111/jpim.12125.

Ye, J., \& Kankanhalli, A. (2013). Exploring innovation through open networks: a review and initial research questions. IIMB Management Review, 25(2), 69-82. http://dx.doi.org/10.1016/j.iimb.2013.02.002. 